recommendation is to be found in the joint consultation document.

It gives me great pleasure to announce that it is envisaged that a follow-up conference will be arranged by the Centre for Corporate Law and Practice under the auspices of the two Law Commissions during the second half of the year, on a second joint consultation paper eagerly awaited by especially every venture capitalist in the UK, dealing with the review of the Limited Partnership Act 1907. There are also a number of 'firsts' for this conference, which I am glad to be allowed to mention. This is the first conference arranged by the Centre for Corporate Law and practice under my directorship, the first conference by the Centre dealing exclusively with the law of partnership, and the first conference offered by the Centre under the joint auspices of both Law Commissions (as far as I know, it is also the first conference in which Law Commissioners from both countries are participating).

Last but not least, this is the first conference in the United Kingdom on the joint consultation paper and, I am sure, the fist conference on partnership law in the United Kingdom ever to be so well attended. The IALS is very grateful to the two Law Commissions, and Judge Diana Faber, for their support and encouragement.

\section{Professor Johan Henning}

Director, Centre for Corporate Law and Practice, Institute of Advanced Legal Studies; Dean, Faculty of Law, University of the Free State, Blocmfontein

\title{
The impact of the Human
} Rights Act 1998 on evidence and disclosure in judicial review proceedings

\author{
by Jonathan Bracken
}

\section{INTRODUCTION}

As public awareness of the Human Rights Act 1998 (HRA) develops it is likely to have a significant impact on the volume and nature of judicial review proceedings. The new grounds provided by the HRA for challenging the actions of public authorities will inevitably lead to changes in the way the Administrative Court deals with such cases. As the Bowman Report (Review of the Crown Office List, chaired by Sir Jeffery Bowman, March 2000), noted:

... under the Human Rights Act, the courts will have to spend more time establishing questions of fact in addition to questions of law. For example, in deciding whether interference with a right can be justified, they may need to give stricter scrutiny to the factual basis of the decision or consider the wider social context. In the past, very little time has been taken on factual matters and discovery and cross examinations have been rare.' (Chap. 5, para. 8 )
The most noticeable changes in judicial review proceedings are likely to be in relation to:

- the evidence considered by the court, and

- the growing need for the court to order disclosure.

As the Bowman Report states, 'further evidence may be necessary under the Human Rights Act.'(Chap. 5, para. 70), and 'orders for discovery [as it was then known] may well be required more frequently in the future, particularly in relation to Human Rights Act cases.' (Chap. 5, para. 69)

Neither the Civil Procedure Rules nor the HRA provide detailed guidance on how judicial review proceedings need to be adapted to cope with this change. The European Convention on Human Rights is equally silent on the issue - evidence and disclosure merely being a facet of the Article 6 right to a fair trial - and the jurisprudence 
of the European Court of Human Rights ('the Strasbourg Court') provides little assistance.

In Schenk v Switzerland ((1991) 13 EHRR 242), the Strasbourg Court held:

'While Article 6 of the Convention guarantees the right to a fair trial it does not lay down any rules on the admissibility of evidence as such, which is therefore primarily a matter for regulation under national law.'

The issue of procedure was briefly considered by the Strasbourg Court in Kaufman v Belgium (an Article 6 fair trial case relating to prosecution disclosure in criminal proceedings) which held that:

'Everyone who is a party to... proceedings should have a reasonable opportunity of presenting his case to the court under conditions which do not place him at a substantial disadvantage vis à vis his opponent.' ((1986) 50 DR 98)

This lack of formal rules or guidance will enable advocates to persuade the domestic courts to be innovative in admitting evidence and ordering disclosure in the interests of giving proper effect to Convention rights. In order to do so they will need to have a clear understanding of the nature and effect of the Convention rights, how they will alter the issues which the court must address in judicial review proceedings and the manner in which that must be done.

\section{THE NATURE OF CONVENTION RIGHTS}

Judicial review proceedings which rely upon the HRA will not allege that a public authority has acted wrongly or perversely but simply that it has acted in a manner which is contrary to a Convention right. Consequently, the nature of those rights will have a direct bearing on the evidence which a court will need to consider in such proceedings.

Whilst a small number of Convention rights are absolute (e.g. the Article 2 prohibition of torture inhuman or degrading treatment) most are subject to certain limitations or qualifications which are expressed in broadly similar terms. Thus, Article 8 , para. 2, permits interference with the right to respect for private and family life to the extent that such interference is:

(1) in accordance with the law; and

(2) is necessary in a democratic society in the interests of one of a specified list of public policy objectives (e.g. national security).

The issue of whether limitation of a Convention right is prescribed by law has been interpreted narrowly by the Strasbourg Court to mean that an ascertainable legal regime must exist and that administrative notices, guidance, etc., do not amount to prescription by law. For example, In Malone v UK (1984) 7 EHRR 14, interception of communications on the basis of guidance issued by the Association of Chief Police Officers was held to be unlawful. That case led to the passing of the Interception of Communications Act 1985. The UK Government has recognised that generally some form of legislation is necessary to meet the 'prescribed by law' test and it seems likely that the domestic courts will adopt that view.

Notions of what is 'necessary in a democratic society' present much more difficulty. That test is also rendered in some cases as one of 'pressing social need' but in essence it has two components, that the action is:

(1) in pursuit of a legitimate aim; and

(2) proportionate.

The legitimate aim is in most cases is self-evident, in the sense of being in pursuit of one of the enumerated qualifications or limitations set out in the relevant Convention Article.

The concept of proportionality, although understood by the domestic courts, has not been widely applied and its application under the HRA will result in fundamental shifts in thinking, particularly in relation to the notion of reasonableness as it is understood by public lawyers.

The need for the domestic courts to consider evidence of what is necessary in a democratic society or constitutes a pressing social need will require them to balance policy and political issues in a way that they have never had to do before. This obligation on the judiciary to establish objective standards of democratic necessity has been described by Sir William Wade as 'the brave new world of interpretation that will confront the judiciary' (Wade, 'Human Rights and the Judiciary' [1998] EHRLR 520) and will have major consequences for evidence and disclosure.

\section{PROPORTIONALITY IN THE UNITED KINGDOM}

Hitherto the court has only been required to make judicial review decisions on the basis that a public authority has acted unlawfully or irrationally. The factual evidence has rarely been disputed. In relation to unlawful acts, the court's role has been to consider whether the public authority acted in contravention of prescribed rules, having regard to public law doctrines such as whether the authority exercised its power for a proper purpose. Rarely has the court needed to balance closely competing arguments.

Similarly, in relation to irrationality, the Wednesbury reasonableness test set a high threshold which left little margin for closely competing arguments. That test as described by Lord Diplock in Council of Civil Service Unions $v$ Minister for the Civil Service ([1985] AC 375) is:

'A decision which is so outrageous in its defiance of logic or accepted moral standards that no sensible person who had applied his mind to the question to be decided could have arrived at it.' 
Where fundamental rights are involved, the court has narrowed the test, applying the test approved in $R v$ Ministry of Defence, ex parte Smith ([1996] QB 517):

'The court may not interfere with the exercise of an administrative discretion on substantive grounds save where the court is satisfied that the decision is unreasonable in the sense that it is beyond the range of responses open to a reasonable decision-maker.'

However, balancing closely competing arguments remains a novel concept in judicial review and, as Lord Ackner commented in $R{ }_{v}$ Secretary of State for the Home Department ex parte Brind ([1991] 1 AC 696 at 762), as compared with Wednesbury reasonableness the principle of proportionality is 'a different and severer test'.

\section{EXISTING PRACTICE}

The absence of any need to balance closely competing arguments has shaped the court's attitude to the evidence it will hear and its willingness to order disclosure. Traditionally, judicial review cases have been heard on the basis of affidavit evidence and the claim set out by the applicant, and generally the court has been reluctant to accept further evidence except where that evidence would assist the court:

(1) to understand more clearly the nature of the factual material before the body whose decision was being challenged;

(2) to determine any matters of facts on which that body's jurisdiction depended;

(3) to determine whether that body had complied with an essential procedural requirement; or

(4) by establishing proof of any alleged misconduct by that body or its members.

Equally, the court has been reluctant to permit crossexamination. Although Lord Diplock made clear in O'Reilly v Mackman ([1983] 2 AC 237), that cross examination was available in judicial review cases and 'should be allowed whenever the justice of the particular case so requires', he went on to make it clear that a public authority's finding of fact was not open to review and warned against allowing cross examination on the grounds that it 'presents the court with the temptation, not always easily resisted, to substitute its own view of the facts.'

Similarly, although disclosure is available in judicial review cases, it is not an inherent right. The court has taken the view that it is appropriate in fewer cases on judicial review and therefore its use has generally been circumscribed. In Inland Revenue Commissioners $v$ National Federation of Self-Employed and Small Businesses Limited ([1982] AC 617), Lord Scarman said that disclosure in judicial review should not be ordered:

'unless and until the court is satisfied that the evidence reveals reasonable grounds for believing that there has been a breach of public duty; and it should be limited strictly to documents relevant to the issue which emerges from the affidavits.'

This reluctance on the part of the court means that it has been rare for disclosure to be secured in judicial review cases and in practice it has only been provided where the court is convinced that the content of affidavits is inaccurate or where the need has been established to look behind the affidavits.

\section{THE CHALLENGE AHEAD}

The Civil Procedure Rules contain no new rules on evidence and disclosure to deal with the developments which will take place in judicial review. It is therefore up to practitioners and the courts to devise new solutions within the existing framework, taking account of the concept of proportionality, the obligation on the court as a public authority to act consistently with the Convention (and, in particular, to respect the Article 6 right to a fair trial) and its obligation under section 3 of the HRA to take account of the case law of the Strasbourg Court. The solutions devised will largely depend upon four factors:

(1) the nature of the factual evidence which is accepted by the court;

(2) the scope for third party intervention;

(3) the manner in which Convention rights are pleaded and applied; and

(4) the application of the margin of appreciation.

\section{Evidence of the facts}

The HRA will require courts to adopt a fundamentally different approach to evidence, the concept of proportionality leading to a more intensive review of the facts and the substantive merits of decisions. As a consequence respondents will need to adduce evidence of the facts which form the basis of their decisions and of the decision-making processes which caused them to believe their actions were necessary and proportionate. It is likely that these considerations will require the court to admit evidence of the 'legislative facts' which gave rise to a particular policy.

The notion of legislative facts, which go to the basis of policy, as opposed to the 'adjudicative facts' which only relate to the dispute between the parties, is an American jurisprudential concept characterised by the so-called 'Brandeis brief' (named after Oregon's counsel, Louis Brandeis, who was later a Supreme Court justice), submitted to the United States Supreme Court in Muller v Oregon (208 US 412 (1908)), which contained two pages of legal argument supported by 100 pages of legislative facts, principally socio-economic data. Since then the use of Brandeis briefs has been common in proceedings before the US Supreme Court (e.g. in the landmark case of Brown $v$ Board of Education (347 US 483 (1954), a 
Brandeis brief was submitted providing evidence on the sociological and psychological effects of racial segregation in schools.

In judicial review proceedings the adjudicative facts the effect which a particular decision has had on the claimant - can be determined from the affidavits. The legislative facts - how the decision is justified in public policy terms - requires more searching consideration and the potential use of Brandeis briefs to provide that evidence has not been overlooked by the judiciary. As Henry LJ observed in $R v$ Ministry of Defence, ex parte Smith ([1996] QB 517):

'if the Convention were... part of our domestic law, ... the court... might well ask for more material than the adversarial system normally provides such as a Brandeis brief.'

\section{Third party intervention}

In other jurisdictions third parties play an important role in judicial review proceedings by providing the courts with Brandeis or other amicus briefs and it is likely that third party intervention will become an increasingly significant part of judicial review proceedings.

The HRA does not provide a general right of third party intervention but the Lord Chancellor, during the proceedings on the Human Rights Bill, made it clear that the expectation was that the practice of non-governmental organisations filing amicus briefs would develop and that section 7(3) HRA (which establishes the 'victim' test as the standing to bring judicial review proceedings) 'would not prevent the acceptance by the courts in this country of non-governmental organisation briefs.' (Hansard, HL 24 November 1997, cols. 825-833). Further, Rule 54.17 of the Civil Procedure Rules enables the court to permit any person to file evidence or make representations at the hearing of a judicial review case.

Third party intervention has often proved crucial to determining legislative facts before the Strasbourg Court. In Young James \& Webster v United Kingdom ((1982) 4 EHRR 38), neither the applicants nor the government were willing to present arguments that the 'closed shop' was necessary in a democratic society and evidence was accepted from the Trades Union Congress on that point. Similarly, in Sheffield and Horsham $v$ United Kingdom (decision A/946, 30 July 1998), liberty was permitted to provide a comparative study on the legal recognition of transsexuals in other signatory states.

More recently the House of Lords has shown itself willing to accept amicus briefs. In $R_{v}$ Secretary of State for the Home Department ex parte Thompson and Venables ([1998] AC 407), the House of Lords accepted written submissions from JUSTICE on the requirements imposed on the United Kingdom as a signatory to the UN Convention on the Rights of the Child, and in $R v_{v}$ Bow Street Stipendiary Magistrate ex parte Pinochet ([1999] 2 WLR 827), the court heard oral submissions from Amnesty International.
The use of third party intervention has also extended to judicial review proceedings and In $R v$ Lord Chancellor ex parte Witham ([1997] 2 All ER 779), the Public Law Project was permitted to submit an affidavit, which read more like a Brandeis brief, setting out the circumstances in which the voluntary sector had subsidised non-legally aided applications to the courts where the applicant could not afford to pay the court fees.

\section{Applying the Convention}

In putting arguments to the court, practitioners need to derive the maximum benefit from their interpretation of the Convention rights. Simply interpreting the Convention as a schedule to a UK statute would result in the loss of valuable arguments and it must be recognised that the Convention:

- should be given a purposive interpretation;

- is a living document to which the ECHR case law gives a contextual interpretation (Tyrer $v$ United Kingdom (1978) 2 EHRR 1);

- assumes certain democratic norms, for example a pluralistic, tolerant and broadminded society, exists in signatory states (Handyside $v$ United Kingdom (1976) 1 EHRR 737);

- in its application in the United Kingdom, provides an opportunity to re-interpret or narrow the Strasbourg Court's margin of appreciation.

\section{The margin of appreciation}

The Strasbourg Court has permitted a wide margin of appreciation in its interpretation of the Convention, in recognition of the fact that signatory states' governments and courts are better able to determine whether specific social policy is appropriate for local circumstances. The Strasbourg Court has never applied the Convention as a human rights 'code', requiring the same uniform solution to be adopted by each national authority, but has exercised a restrained judicial review, giving due deference to domestic authorities within a range or limits set by the court against what is proportionate.

In theory the margin of appreciation should not apply before the domestic courts but in practice it will not disappear altogether, other than in name. This is because the domestic courts have always sought to avoid substituting their own view for that of a public body whose decision has been challenged in judicial review proceedings. As Lord Hope of Craighead observed in $R v$ Director of Public Prosecutions ex parte Kebilene ([2000] HRLR 93):

$\therefore$ the Convention should be seen as an expression of fundamental principles rather than as a set of mere rules. The questions which the courts will have to decide... will involve questions of balance between competing interests and issues of 
proportionality. In this area difficult choices may have to be made by the executive or legislature between the rights of individuals and the needs of society. In some circumstances it will be appropriate for the courts to recognise that there is an area of judgement within which the judiciary will defer, on democratic grounds, to the considered opinion of the elected body or person whose act or decision is said to be incompatible with the Convention...'.

The obligation imposed on the domestic court by the HRA to take account of the Strasbourg jurisprudence will mean that the margin of appreciation in such case law will determine the minimum standard to be applied by the domestic court but that court will then be free to refine and narrow that case law to meet domestic needs. The scope for the court to narrow the case law and fill the void left by the margin of appreciation is an opportunity which practitioners can exploit and this will be particularly so where the case law concerns a decision of the Strasbourg Court in relation to a signatory state other than the UK.

\section{CONCLUSION}

The Bowman Committee did not recommend changes to the court rules in relation to judicial review to reflect the impact of the HRA on evidence and disclosure. Instead it followed the common law tradition of leaving it to practitioners and the courts to devise innovative solutions to meet the new challenges. It will be up to those involved in judicial review proceedings to persuade the courts to seize the opportunities which the HRA provides.

\section{Jonathan Bracken}

LLB (Hons), solicitor. Partner, Bircham Dyson Bell, London. Schalar in Residence US Law Library of Congress.

\section{America}

\section{What the US needs is a new electric meter}

\section{by Edward L. Flippen}

Like Presidents Nixon and Carter before him, President George W. Bush has developed a national energy policy. What is different about President Bush's policy is his proposal that the US adopt comprehensive electric industry legislation that promotes competition, encourages new generation, protects consumers, enhances reliability, and promotes renewable energy. In other words, he has made a national electricity policy a central part of his overall national energy policy.

One need not be a rocket scientist to know that the US needs additional power plants to meet increased demand during peak periods. If the answer to the increased demand is so simple, then why do we continue to experience shortages in certain parts of the country? The problem with building power plants (besides our 'not in my backyard' syndrome) is that additional plants, by themselves, are not a cost-effective answer to the electricity shortage. Whether in a state that continues with traditional rate regulation, or in a state such as California that has deregulated power plants, the consequence of adding power plants, without addressing pricing, will be the same - inefficiencies.
The real cost of power changes continuously throughout the day. Yet, with only a few exceptions, customers see only a monthly price on their bills. They, therefore, have no incentive to reduce their consumption at peak periods, and increase consumption in off-peak periods, because they do not pay for electricity on an hourly or some other interval basis. Under this traditional pricing method, building additional power plants will not necessarily ensure the availability of adequate electric supplies. The added costs of those plants will simply be rolled in with the existing cost structures of power suppliers and the average costs passed on to consumers in their monthly bills. Consumers will continue to demand greater amounts of electricity at peak periods, and more plants will be built to meet those demands instead of ensuring better utilisation from existing plants.

There is no doubt the US needs additional power plants. But, perhaps more important, we need a better pricing mechanism, such as time of use rates. Notably, however, flexibility in pricing is hampered by the limited features of the mechanical meters traditionally used by utilities to measure customer consumption. Such meters 